\title{
ELÉGEDETTSÉG-VIZSGÁLAT A ZEMPLÉN KALANDPARK ÉS AZ OXYGEN ADRENALIN PARK LÁTOGATÓI KÖRÉBEN
}

\author{
Boda Eszter Judit - Müller Anetta - Bácsné Bába Éva
}

\begin{abstract}
Absztrakt: Modern világunk szűkölködik a szabad felhasználású idő mennyiségében, ezért nagy jelentősége van annak minőségi eltöltésének. Élmények szerzésére és a természet közelségére építenek a különböző kalandparkok, melyek közül az Észak-Magyarországi régió két meghatározó parkját vizsgáltuk a fogyasztói elégedettség oldaláról. Kérdőíves megkeresésünk fókuszában olyan szolgáltatási elemek meglétének fontossága és azzal való elégedettség állt, melyek specifikusan jellemzik a kalandparkok kínálatát. Kereszttábla elemzés és Chi²-teszt segítségével kerestük az összefüggéseket a fontosság és az elégedettség mentén. A vizsgálatok komoly összefüggéseket mutattak a két tényező között, melyeket mindenképpen érdemes figyelembe venni az egyre kiélezettebb piacon, a megújulás és a vevők teljes elégedettségének érdekében.
\end{abstract}

\begin{abstract}
Our modern world is reluctant to spend free time, so its quality is of very importance. Various adventure parks are built around the experiences, pleasure and the proximity of nature, of which two dominant parks of the Northern Hungary region were examined from the point of view of consumer satisfaction. In the focus of our questionnaire, was on the importance and satisfaction of service elements that specifically characterize the supply of adventure parks. Through cross-board analysis and Chi2-test, we looked for relationships in importance and satisfaction. The studies have shown a great deal of correlation between the two factors, which should be taken into account in the ever-expanding market, in order to make renewal and complete satisfaction of the customers.
\end{abstract}

Kulcsszavak: aktív turizmus, kalandpark, szabadidő-eltöltés, fogyasztói elégedettség vizsgálat

Keywords: active tourism, adventure park, leisure time, consumer satisfaction examination

\section{Bevezetés}

Az utóbbi években a szolgáltatások minősége egyre fontosabb a szolgáltatóknál, így a rekreációban és a turizmusban is igaz, hogy a minőség befolyásolja a vendégelégedettséget, hiszen a versenyképesség egyik meghatározó elemévé vált. „A szolgáltatókat a fogyasztók egyre inkább a minőség alapján különböztetik meg egymástól”. (Papp-Rózsa, 2003: 4)

A vevői elégedettség a szolgáltatók jövedelmezőségére hatással van, mivel a vevői elégedettség és a vevői lojalitás között összefüggés tapasztalható. magas szintü vevő elégedettség akkor alakul ki, amennyiben a magas minőségü termék és a hozzá kapcsolódó szolgáltatás találkozik a vevői igényekkel. (Jones-Sasser, 1995) A vevői elégedettség pedig szükséges, de nem elégséges feltétele a vevői lojalitásnak. Egyes kutatások tanulságai szerint a magas vevői elégedettség lojalitást eredményez Dumond (2000), megtartja a vevőt és újakat vonz.

A vevői elégedettség szorosan összefügg a szolgáltatás minőségével. „Minőség pedig az, amit a fogyasztó annak ismer el." (Parasuraman et al., 1985) Chikán és Demeter (1999: 504) szerint: a piaci, fogyasztói minőség „kifejezi azt, hogy valamely meghatározott termék vagy szolgáltatás milyen mértékben elégíti ki egy bizonyos felhasználó, fogyasztó igényeit."

A turizmusban a WTO Minőség Programjának igazgatója a minőséget az alábbiak szerint határozta meg: „a fogyasztói igények elfogadható áron történő, 
legális kielégítése". (Halassy, 1999) Napjainkban a fogyasztói igények folyamatosan változnak, így a minőség tartalmi elemei sem állandóak (Papp, 2003; Bácsné et al., 2018), melyekre a turisztikai termékek fejlesztése során figyelembe kell venni. Több saját egészségturisztikai kutatásunk igazolta, hogy a szolgáltatások extenzív és intenzív fejlesztése: a folyamatos attrakciófejlesztés (csúszda vagy szauna elemek, élményelemek), design-elemek fejlesztése, kapacitásbővítés a medencék vízfelületének növelése, gyerekbarát szolgáltatások kialakítása a magas vendégelégedettséget eredményezte. (Müller-Kórik, 2009, Müller et. al., 2016) Egy karcagi és cserkeszőlöi fürdőkutatás (Könyves et. al., 2005), mely a vendégelégedettséget mérte, arról számol be, hogy a környezeti elemek, az élményelemek, a szabadidős programok széles választéka fontosak a vendégek számára. A környezeti kultúra, mint preferált érték nem csak az egészségturizmusban igaz, de a turizmus más termékei esetében is fontos. (Könyves és Müller, 2001, Müller et. al., 2009; Bácsné, 2014a; Bácsné 2014b)

A turizmusban lévő minőségalapú védjegyek és díjak is igen fontos szerepet töltenek be ebbe a minőség-orientált szolgáltatáskínálatban, hiszen a szolgáltatások minőségét hangsúlyozzák és fémjelzik. (Könyves et al., 2006a, 2006b, KönyvesMüller, 2007)

Az élménykeresés egyik fontos motivációja a XXI. század turistájának. „A turisztikai termékek esetében nem annyira az ár/érték arányra figyelnek a fogyasztók, hanem a befektetett energia, erőfeszítés (nemcsak pénz) és a cserébe kapott élmény viszonyára." - hangzott el a WTO krakkói konferenciáján. (Halassy, 1999) Erre az élmény-centrikusságra épít a kaland parkok kínálata és termékfejlesztése is.

A kalandparkok létjogosultságára kézzel fogható bizonyíték, hogy a 2000-es évek óta gombamód szaporodtak hazánkban a különféle kínálattal rendelkező, aktív kikapcsolódást és élményszerzést nyújtó parkok (Boda et al., 2018). Jónás-Berki (2010, 148-149. o.) vizsgálatai alapján négy különböző típust határozott meg:

1. „Komplex kínálati összetételü, nagy- és középvárosi térhez kapcsolódó parkok

2. Komplex kínálati összetételü, természeti környezet bázisú idegenforgalmi centrumokhoz kapcsolódó parkok

3. Egy-egy játékelemre specializálódó nagy- és középvárosi szabadidőparkok

4. Egy-egy játékelemre specializálódó, idegenforgalmi centrumokhoz kapcsolódó parkok"

A publikációnkban vizsgált két kalandpark iskolapéldája az első két típusnak. Középvárosi térhez kapcsolódik a sátoraljaújhelyi Zemplén Kalandpark, melynek kínálati elemei között szerepelnek szezonális és szezontól függetlenül működő „játékok”. Évszaktól függő például a fiatalokat megcélzó „Sólyom” névre keresztelt extrém átcsúszópálya, vagy a hazánkban és a térségben leghosszabbnak tartott bob pályája, de a kalandparkok legjellemzőbb elemeként számon tartott kalandtúra pályák müködése is szünetel, amennyiben az időjárás nem megfelelö. Egész évben üzemel és várja a kihívásokra vágyó látogatókat a mászófal központ. (A Zemplén Kalandpark honlapja) 
Természeti környezetben, idegenforgalmi centrumhoz kapcsolódó kalandpark típusba sorolható a sástói Oxygen Adrenalin Park. A Mátrában található park ötvözi a turisztikai és a rekreációs lehetőségeket. Extrém játékai között szerepel például az óriáshinta, a canopy, az erdei kalandpark, turizmushoz köthető elemei az erdei labirintus, a függőhíd, vagy a haditechnikai eszközöket bemutató kiállítás. (Az Oxygen Adrenalin Park honlapja)

Az alábbi táblázatban (1. táblázat) összehasonlítottuk a vizsgált szolgáltatók kínálati palettáját. A felosztás a szolgáltatások jellege szerint történt. Három kategóriát képeztünk, aszerint, hogy kipróbálása élményt nyújtó-e, az élmény mellett extrém jelleget is visel-e, illetve speciálisan gyermekeket megcélzó-e.

\section{1. táblázat: A vizsgálatban szereplő kalandparkok szolgáltatás kínálatának} összehasonlítása

\begin{tabular}{|c|c|c|}
\hline & Oxygen Adrenalin Park & Zemplén Kalandpark \\
\hline Élmény-elemek & $\begin{array}{l}\text { Bob pálya, bringóhintó, erdei kalandpark, } \\
\text { erdei labirintus, eurobungy, függőhíd, } \\
\text { haditechnikai kiállítás, hajtány, íászat, } \\
\text { paintball, oxygen express, trambulin, } \\
\text { trükkös kerékpár, tutaj, vízi akadálypálya, } \\
\text { water roller }\end{array}$ & $\begin{array}{l}\text { Libegő, bob pálya, gör- és } \\
\text { müjégkori pálya, sípálya, } \\
\text { Tubby pályák, „Dongó” } \\
\text { kabinos kötélpálya, kilátó }\end{array}$ \\
\hline $\begin{array}{l}\text { Extrém-jellegü } \\
\text { játékok }\end{array}$ & Óriáshinta, canopy, $360^{\circ}$-os hinta & $\begin{array}{l}\text { „Sólyom” átcsúszó pálya, } \\
\text { mászófal, } 3 \text { féle kalandtúra } \\
\text { pálya }\end{array}$ \\
\hline $\begin{array}{l}\text { Játékok } \\
\text { gyerekeknek }\end{array}$ & $\begin{array}{l}\text { Elektromos jet-ski, erdei tornapálya, } \\
\text { gyermek kalandpark, játszóház, kalózhajó, } \\
\text { kisállat simogató, kowboykids, légvár, } \\
\text { gyermek quad pálya, toronycsúszda, } \\
\text { vízigömböc }\end{array}$ & $\begin{array}{l}\text { Tanösvény, játszótér, „zöld” } \\
\text { kalandtúra pálya }\end{array}$ \\
\hline Hasonlóságok & \multicolumn{2}{|c|}{ Bob pálya, kötélpályák, mindhárom jellegű elemmel rendelkeznek a parkok } \\
\hline Különbségek & Szélesebb szolgáltatás kínálat & Extrémebb jellegü elemek \\
\hline
\end{tabular}

A táblázatot vizsgálva kitünik, hogy a hasonlóságok mellett, inkább a különbségek dominálnak. A különbségek jelentik azokat az egyedi elemeket, melyeket a sport és turisztikai szolgáltatók a hasonló kínálattal rendelkező versenytársaktól megkülönböztetik magukat, így az egyedi kínálati elemekkel a versenyképességük nő a piacon. (Müller et al., 2006b) Megállapítható, hogy mind a két park törekszik valami mást, valami egyedit nyújtani versenytársához képest, a mátrai létesítmény szélesebb szolgáltatás-palettájával feltételezhetően a családokat igyekszik megcélozni, míg a zempléni az extrémebb jelleg domborításával a fiatalabb korosztályt.

\section{Anyag és módszer}

Kutatásunk kérdőíves felmérést tartalmazott, mely során az Észak-Magyarország két meghatározó kalandparkjának „fogyasztóit” kérdeztük. A minta 206 fös, melynek 57,3\%-a (118 fö) a Zemplén Kalandparkban, míg 42,7\%-a (88 fö) az Oxygen Adrenalin Parkban járt és a látogatása alapján mondott véleményt. Elmondható a 
mintáról továbbá, hogy 43,2\%-a (89 fö) férfi, 56,8\%-a (117 fö) nő, életkor tekintetében a sokaság 79,1\%-a (163 fö) 30 év alatti, többségük (43,7\%-uk, 90 fö) városban él. Nagy részüknek hétköznaponként kevesebb, mint 3 óra szabadideje van (69,8\%, 150 fö), viszont a hétvégéken megnövekszik a megkérdezettek szabad felhasználású ideje, a leggyakoribb válaszként $(41,3 \%, 85$ fö) a 4-5 órát jelölték. Kíváncsiak voltunk a válaszadók sporteszköz és sportfelszerelési költésére, illetve, hogy milyen típusú márkákat részesítenek előnyben. A beérkezett válaszok alapján elmondható, hogy a minta nagy része $(35,8 \%, 74$ fö) évente kevesebbet költ 25000 forintnál sporteszközre és sportfelszerelésre és költései során a természeti sportokhoz köthető prémium márkákat a minta nagy része $(42,7 \%, 88$ fö) egyáltalán nem részesíti előnyben, nem jellemző vásárlására. Vizsgáltuk továbbá a szolgáltatásokkal való elégedettségüket is. A beérkezett adatokat SPSS 22.0 program segítségével elemeztük, mellyel kereszttábla és $\mathrm{Chi}^{2}$-próba segítségével kerestük az összefüggéseket az elégedettségi mutatókban.

\section{Feltételezéseink:}

- A szolgáltatáskínálatot vizsgálva is látható, hogy mind a két park igyekszik kitünni, egyedivé válni valamivel a régióban, melynek következtében más fogyasztói réteget céloznak meg.

- Az elégedettség és az egyes szolgáltatások meglétének fontossága között pozitív kapcsolat van.

\section{Eredmények és értékelésük}

Vizsgálatunk során elégedettségi tesztet végeztünk a két park látogatói körében. Ehhez segítségük hívtuk Ryan és mtsai (2010) által témaparkokra elkészített kérdőívét, melyet specializáltunk a kalandparkokra. 15 féle tényezőről kérdeztük a látogatókat és nem csak elégedettségükre, hanem a tényező fontosságára is fókuszáltunk, vagyis mennyire érzi jelentősnek a fogyasztó annak minőségi meglétét. Az elemzett faktorok között szerepelt többek között a park szórakoztató funkciójának megléte, sokszínü programkínálata, aktív kikapcsolódást nyújtó mivolta, a park hangulata/atmoszférája/design eleme/összképe/benyomása, extrémitás/kihívást jelentő szolgáltatások megléte. Ezen állításokat/tényezőket 1-4ig terjedő kényszerválasztásos skálán kellett értékelni, ahol az 1: egyáltalán nem fontos vagy egyáltalán nem elégedett, a 4: nagyon fontos vagy nagyon elégedett minősítést jelentett. A 2. táblázat ennek eredményeit foglalja össze. Kitünik, hogy a fogyasztók által top3-ba választott tényezők a tisztaság, a biztonság és szórakoztató funkció megléte. Az elégedettséget vizsgálva a legmagasabb átlaggal a társas szabadidő-eltöltés, az aktív kikapcsolódási és a szórakoztató funkció került kiválasztásra. A mintában szereplők által legfontosabbnak titulált tisztaság az elégedettség tekintetében „,csupán” 3,35-ös átlagot szerzett, míg a biztonság az elégedettségnél 3,53-as minősítést kapott. Érdekes eredmény, hogy mely tényezőket tartják a megkérdezettek a legkevésbé fontosnak. Ezek: étkezési lehetőség megléte, extrémitás és kihívást jelentő szolgáltatások megléte (mely azért különös eredmény, hiszen ez az egyik olyan tényező, mely igazán kalandpark-specifikus) és a könnyen megközelíthető mellékhelység voltak. Az elégedettség oldaláról átlagosan az 
étkezési lehetőség meglétét, a kevés várakozási időt és a belépő ár-érték arányát értékelték a legalacsonyabbra. A kereszttábla metszéspontjait szemlélve megkaptuk a minősítések tekintetében legnépszerübb osztályozásokat. Érdekes, hogy a fontosság tekintetében minden tényezőnél a legmagasabb 4-es jelölés volt a legtöbbet előforduló (vagyis nagyon fontosnak titulált). Az elégedettségnél a belépő ár-érték aránya, az étkezési lehetőségek megléte és a kevés várakozási idő kapott 3ast (vagyis inkább elégedettek voltak, de nem teljes mértékben azért a szóban forgó szolgáltatásokkal), a többi faktor ebben az esetben is a legjobb minösítést, a 4-est kapta.

\section{2. táblázat: Összefoglaló táblázat a fontossági és elégedettségi adatokról}

\begin{tabular}{|c|c|c|c|c|}
\hline $\begin{array}{l}\text { Mennyire } \\
\text { fontosnak/mennyire elégedett az } \\
\text { alábbiakkal a meglátogatott } \\
\text { kalandparkkal kapcsolatban? }\end{array}$ & $\begin{array}{l}\text { Fontosság } \\
\text { átlag } \\
\text { értéke }\end{array}$ & $\begin{array}{l}\text { Leggyakoribb } \\
\text { minősítés } \\
\text { (érték és } \\
\text { jelölők \%-a) }\end{array}$ & $\begin{array}{l}\text { Elégedett- } \\
\text { ség átlag } \\
\text { értéke }\end{array}$ & $\begin{array}{l}\text { Leggyako- } \\
\text { ribb } \\
\text { minősítés }\end{array}$ \\
\hline $\begin{array}{l}\text { Biztonságos megközelíthetőség, } \\
\text { biztonságos utak a park területén és } \\
\text { biztonságos eszközök }\end{array}$ & 3,70 & 4 és $76,7 \%$ & 3,53 & 4 és $61,7 \%$ \\
\hline $\begin{array}{l}\text { Tiszta környezet, a mosdók } \\
\text { higiéniája }\end{array}$ & 3,74 & 4 és $78,2 \%$ & 3,35 & 4 és $49 \%$ \\
\hline $\begin{array}{l}\text { A családdal, barátokkal együtt } \\
\text { eltöltött szabadidős tevékenység }\end{array}$ & 3,68 & 4 és $75,7 \%$ & 3,71 & 4 és $75,7 \%$ \\
\hline $\begin{array}{l}\begin{array}{l}\text { Könnyen hozzáférhető } \\
\text { mellékhelység }\end{array} \\
\end{array}$ & 3,41 & 4 és $56,3 \%$ & 3,19 & 3 és $44,2 \%$ \\
\hline A park szórakoztató funkciója & 3,70 & 4 és $77,7 \%$ & $\mathbf{3 , 5 5}$ & 4 és $65 \%$ \\
\hline Aktív kikapcsolódást nyújt & 3,66 & 4 és $73,3 \%$ & 3,67 & 4 és $72,3 \%$ \\
\hline A belépő ára, ár-érték aránya & 3,55 & 4 és $67,5 \%$ & 3,15 & 3 és $39,8 \%$ \\
\hline Sokszínü programkínálat & 3,59 & 4 és $67,5 \%$ & 3,25 & 4 és $45,6 \%$ \\
\hline $\begin{array}{lr}\begin{array}{l}\text { A kiszolgáló } \\
\text { (szakértelem, } \\
\text { segítőkészség stb.) }\end{array} & \begin{array}{r}\text { személyzet } \\
\text { udvariasság, }\end{array} \\
\end{array}$ & 3,59 & 4 és $67,5 \%$ & 3,43 & 4 és $54,4 \%$ \\
\hline $\begin{array}{l}\text { Étkezési lehetőségek megléte, annak } \\
\text { kínálata és minősége }\end{array}$ & 3,27 & 4 és $50 \%$ & 3,10 & 3 és $41,7 \%$ \\
\hline $\begin{array}{l}\text { Kevés várakozási idő alatt igénybe } \\
\text { vehető szolgáltatások (kevesebb, } \\
\text { mint } 10 \text { perc) }\end{array}$ & 3,56 & 4 és $65 \%$ & 3,12 & 3 és $39,8 \%$ \\
\hline $\begin{array}{l}\text { A park hangulata, atmoszférája, } \\
\text { design eleme, összképe, benyomása }\end{array}$ & 3,50 & 4 és $59,7 \%$ & 3,41 & 4 és $54,4 \%$ \\
\hline $\begin{array}{l}\text { Extrémitás, kihívást jelentö } \\
\text { szolgáltatások megléte }\end{array}$ & 3,28 & 4 és $49,5 \%$ & 3,30 & 4 és $49 \%$ \\
\hline $\begin{array}{l}\text { A helyszíni információ } \\
\text { biztosítottsága, egyértelmüsége }\end{array}$ & 3,50 & 4 és $62,1 \%$ & 3,38 & 4 és $53,4 \%$ \\
\hline $\begin{array}{l}\text { A kalandpark honlapja, a honlapon } \\
\text { található információk }\end{array}$ & 3,44 & 4 és $62,6 \%$ & 3,26 & 4 és $44,7 \%$ \\
\hline
\end{tabular}

Forrás: saját kutatás alapján, 2018

A 3. táblázatban kiegészítettük az átlagot a szórás eredményeivel. A top3 átlagoknak van mind a két vizsgálatnál a legkisebb szórása. Kevesebb, mint 0,6 
értékkel térnek el az átlagtól, mely azt jelzi, hogy a minősítések (1-4-es jelölés) kis mértékben tértek el egymástól.

\section{3. táblázat: Összefoglalás a fontossági és elégedettségi tényezők átlag értékeiről} és szórásáról

\begin{tabular}{|l|c|c|c|c|}
\hline $\begin{array}{l}\text { Mennyire érzi fontosnak/ } \\
\text { mennyire elégedett az } \\
\text { alábbiakkal a meglátogatott } \\
\text { kalandparkkal kapcsolatban? }\end{array}$ & $\begin{array}{c}\text { Fontosság } \\
\text { átlag } \\
\text { értéke }\end{array}$ & $\begin{array}{c}\text { Fontossági } \\
\text { értékek } \\
\text { szórása }\end{array}$ & $\begin{array}{c}\text { Elégedettség } \\
\text { átlag értéke }\end{array}$ & $\begin{array}{c}\text { Elégedett- } \\
\text { ségi értékek } \\
\text { szórása }\end{array}$ \\
\hline $\begin{array}{l}\text { Biztonságos megközelíthetőség, } \\
\text { biztonságos utak a park területén } \\
\text { és biztonságos eszközök }\end{array}$ & $\mathbf{3 , 7 0}$ & $\mathbf{0 . 5 9 8}$ & 3,53 & 0.660 \\
\hline $\begin{array}{l}\text { Tiszta környezet, a mosdók } \\
\text { higiéniája }\end{array}$ & $\mathbf{3 , 7 4}$ & $\mathbf{0 . 5 3 1}$ & 3,35 & 0.730 \\
\hline $\begin{array}{l}\text { A családdal, barátokkal együtt } \\
\text { eltöltött szabadidős tevékenység }\end{array}$ & 3,68 & 0.611 & $\mathbf{3 , 7 1}$ & $\mathbf{0 . 5 6 1}$ \\
\hline $\begin{array}{l}\text { Könnyen hozzáférhető a } \\
\text { mellékhelység }\end{array}$ & 3,41 & 0.752 & 3,19 & 0.783 \\
\hline A park szórakoztató funkciója & $\mathbf{3 , 7 0}$ & $\mathbf{0 . 5 9 6}$ & $\mathbf{3 , 5 5}$ & $\mathbf{0 . 6 9 5}$ \\
\hline Aktív kikapcsolódást nyújt & 3,66 & 0.627 & $\mathbf{3 , 6 7}$ & $\mathbf{0 . 5 7 4}$ \\
\hline A belépő ára, ár-érték aránya & 3,55 & 0.722 & 3,15 & 0.791 \\
\hline Sokszínü programkínálat & 3,59 & 0.654 & 3,25 & 0.810 \\
\hline $\begin{array}{l}\text { A kiszolgáló személyzet } \\
\text { (szakértelem, udvariasság, } \\
\text { segítőkészség stb.) }\end{array}$ & 3,59 & 0.6 .39 & 3,43 & 0.714 \\
\hline $\begin{array}{l}\text { Étkezési lehetőségek megléte, } \\
\text { annak kínálata és minősége }\end{array}$ & 3,27 & 0.858 & 3,10 & 0.805 \\
\hline $\begin{array}{l}\text { Kevés várakozási idő alatt } \\
\text { igénybe vehető szolgáltatások } \\
\text { (kevesebb, mint 10 perc) }\end{array}$ & 3,56 & 0.650 & 3,12 & 0.814 \\
\hline $\begin{array}{l}\text { A park hangulata, atmoszférája, } \\
\text { design eleme, összképe, } \\
\text { benyomása }\end{array}$ & 3,50 & 0.675 & 3,41 & 0.712 \\
\hline $\begin{array}{l}\text { Extrémitás, kihívást jelentő } \\
\text { szolgáltatások megléte }\end{array}$ & 3,28 & 0.824 & 3,30 & 0.754 \\
\hline $\begin{array}{l}\text { A helyszíni információ } \\
\text { biztosítottsága, egyértelmüsége }\end{array}$ & 3,50 & 0.731 & 3,38 & 0.790 \\
\hline $\begin{array}{l}\text { A kalandpark honlapja, a } \\
\text { honlapon található információk }\end{array}$ & 3,44 & 0.823 & 3,26 & \\
\hline
\end{tabular}

Forrás: saját kutatás alapján, 2018

A kereszttábla elemzést követően az egyes tényezők esetében a fontosság kontra elégedettség kérdésében elvégeztük a Chi ${ }^{2}$-tesztet, annak érdekében, hogy szignifikáns eltéréseket keressünk. Esetünkben gyakorlatilag teljesen mindegy, hogy melyik változót jelöljük ki függőnek és függetlennek, mégis a fontosságot választottuk a függőnek. 15-ből 10 faktornál mutatott a próba igen erős szignifikáns eltérést, vagyis az elégedettség befolyással bír a szolgáltatások meglétének és jó minőségének fontosságára. A szabadságfok 9-es és 6-os értékeket vett fel. A próba során figyelembe vettük a Gamma együtthatót is, amely pozitív értéket mutatott minden esetben, ezért mondhatjuk, hogy azok, akik magasabb minősítéssel jelölték 
az egyes tényezők elégedettségét, nagyobb jelentőséget tulajdonítottak azok fontosságának is. Összesen 3 tényezőnél nem bizonyítható a szignifikáns összefüggés, ezek a belépő ár-érték arányának, az étkezési lehetőség meglétének és a kevés várakozási időnek a mutatói. Az ár-érték arányt az elégedettségi értékeinél már említettük, hogy a legkevésbé jóra értékelt faktornak jelölték a fogyasztók. Az étkezési lehetőség kérdésköre kalandparkonként eltérő országszerte. Nem a park élményelemeihez szorosan köthető dologról van szó, hanem kiegészítő szolgáltatásról, aminek meglétét nem feltétlenül tartja létszükségletnek a fogyasztó, így vezetőség válogatja, hogy létesítenek-e külön büfét. A két vizsgált parkban van erre mód, viszont, ahogy az eredményekből is kitünik, ennek fontossága és a látogatók ezzel való elégedettsége között nincs kimutatható összefüggés. A várakozási idő kapcsán szintén nem találtunk összefüggést. Ez magyarázható például azzal, hogy szabadidős tevékenységként látogat el az ember egy ilyen kalandparkba és mivel kikapcsolódik, családdal, barátokkal van együtt a szabadban, így jobban tudja azt is tolerálni, ha esetleg egy-egy játékelemnél többet kell várakozni. A vizsgálat igazolta a korábban feltételezz második állításunkat, vagyis pozitív összefüggés van a két vizsgált tényező között. A 4. táblázat foglalja össze a számszerüsített eredményeket.

\section{Következtetés, összefoglalás}

Az irodalmi áttekintés során feltárt kutatások, illetve az általunk folytatott vizsgálat kapcsán kapott eredmények hasonlóságot mutatnak a minőség, a különféle szolgáltatások meglétének fontossága és az elégedettség hármasában. Bizonyosságot nyert, hogy a szolgáltatás megléte és annak minőségi megléte elengedhetetlen versenytényező bármely piacon, így az aktív turizmus szektorában müködö kalandparkok esetében is. A fogyasztói elégedettség tehát vitathatatlanul alapját képezi a jól működő vállalkozásnak, azonban az egyedi szolgáltatások kínálata és a különböző célcsoportokra történő fókuszálás is jelentősen hozzájárulhat a gazdasági növekedéshez (Anderson et al., 1994). Az általunk vizsgált két park annak ellenére, hogy földrajzilag nincsenek messze egymástól, mégis jól működő vállalkozás a saját szektorában, melynek kulcsa egyrészt az eltérő fókuszcsoport, másrészt pedig a látogatók körében meglévő elégedettség. 
4. táblázat: Összefoglaló táblázat a fontosság és elégedettség adatainak $\mathbf{C h i}^{\mathbf{2}}$ vizsgálatáról

\begin{tabular}{|c|c|c|c|c|c|}
\hline & $C h i^{2}$ & Érték & $d f$ & $\begin{array}{l}\text { Gamma } \\
\text { együttható }\end{array}$ & $\begin{array}{l}\text { Legjellemzöbb } \\
\text { jelölés }\end{array}$ \\
\hline $\begin{array}{lll}\begin{array}{l}\text { Biztonság } \\
\text { elégedettség }\end{array} & \text { fontossága } & \text { vs. } \\
\end{array}$ & .000 & $30,455^{a}$ & 9 & .442 & $\begin{array}{c}4-4(106 \text { fó, } \\
51,5 \%)\end{array}$ \\
\hline $\begin{array}{l}\text { Tisztaság } \\
\text { fontossága vs. elégedettség }\end{array}$ & .005 & $18,673^{a}$ & 6 & .436 & $\begin{array}{c}4-4(88 \text { fó, } \\
42,7 \%)\end{array}$ \\
\hline $\begin{array}{l}\text { Társas szabadidős tevékenység } \\
\text { fontossága vs. elégedettség }\end{array}$ & .000 & $75,608^{a}$ & 9 & .810 & $\begin{array}{c}4-4(137 \text { fó, } \\
66,5 \%) \\
\end{array}$ \\
\hline $\begin{array}{l}\text { Mellékhelység hozzáférhetősége } \\
\text { Fontossága vs. elégedettség }\end{array}$ & .000 & $32,505^{a}$ & 9 & .301 & $\begin{array}{c}4-4(58 \text { fó, } \\
28,2 \%) \\
\end{array}$ \\
\hline $\begin{array}{l}\text { Szórakoztató funkció } \\
\text { fontossága vs. elégedettség }\end{array}$ & .000 & $42,810^{a}$ & 6 & .696 & $\begin{array}{c}4-4(120 \text { fó, } \\
58,3 \%) \\
\end{array}$ \\
\hline $\begin{array}{l}\text { Aktív kikapcsolódás nyújtása } \\
\text { fontossága vs. elégedettség }\end{array}$ & .000 & $49,648^{a}$ & 6 & .719 & $\begin{array}{c}-4(127 \text { fó } \\
61,7 \%)\end{array}$ \\
\hline $\begin{array}{l}\text { Belépő ár-érték aránya } \\
\text { fontossága vs. elégedettség }\end{array}$ & .190 & $12,429^{a}$ & 9 & .199 & $\begin{array}{c}4-4(61 \text { fö, } \\
29,6 \%)\end{array}$ \\
\hline $\begin{array}{l}\text { Sokszínű programkínálat } \\
\text { Fontossága vs. elégedettség }\end{array}$ & .000 & $108,690^{a}$ & 9 & .541 & $\begin{array}{c}4-4(78 \text { fö, } \\
37,9 \%) \\
\end{array}$ \\
\hline $\begin{array}{l}\text { Személyzet } \\
\text { fontossága vs. elégedettség }\end{array}$ & .038 & $13,316^{a}$ & 6 & .338 & $\begin{array}{c}4-4(86 \text { fö, } \\
41,7 \%)\end{array}$ \\
\hline $\begin{array}{l}\text { Étkezési lehetöség megléte } \\
\text { fontosság vs. elégedettség }\end{array}$ & .590 & $7,451^{a}$ & 9 & .117 & $\begin{array}{c}4-4(42 \text { fö, } \\
20,4 \%) \\
\end{array}$ \\
\hline $\begin{array}{l}\text { Kevés várakozási idő } \\
\text { fontossága vs. elégedettség }\end{array}$ & .201 & $8,536^{\mathrm{a}}$ & 6 & .165 & $\begin{array}{c}4-4(57 \text { fö, } \\
27,7 \%)\end{array}$ \\
\hline $\begin{array}{l}\text { Összbenyomás } \\
\text { fontosság vs. elégedettség }\end{array}$ & .000 & $32,566^{a}$ & 6 & .527 & $\begin{array}{c}4-4(84 \text { fö } \\
40,8 \%) \\
\end{array}$ \\
\hline $\begin{array}{l}\text { Extrémitást adó szolgáltatások } \\
\text { fontosság vs. elégedettség }\end{array}$ & .000 & $31,866^{a}$ & 9 & .370 & $\begin{array}{c}4-4(63 \text { fö, } \\
30,6 \%) \\
\end{array}$ \\
\hline $\begin{array}{l}\text { Helyszíni információk } \\
\text { fontossága vs. elégedettség }\end{array}$ & .000 & $44,711^{\mathrm{a}}$ & 9 & .567 & $\begin{array}{c}-4(89 \text { fö } \\
43,2 \%)\end{array}$ \\
\hline $\begin{array}{l}\text { A park honlapjának tartalma } \\
\text { fontosság vs. elégedettség }\end{array}$ & .000 & $45,338^{a}$ & 9 & .459 & $\begin{array}{c}4-4(73 \text { fö } \\
35,4 \%) \\
\end{array}$ \\
\hline
\end{tabular}

Forrás: saját kutatás alapján, 2018

A publikáció elkészítését az EFOP-3.6.2-16-2017-00003 számú projekt támogatta. A projekt az Európai Unió támogatásával, az Európai Szociális Alap társfinanszírozásával valósult meg.

\section{Irodalomjegyzék}

Anderson, E. W., Fornell, C., Lehmann, D. R. (1994): Customer Satisfaction. Market Share, and Profitability: Findings from Sweden. Journal of Marketing, 58 (7): 53-66.

Bácsné Bába É., Fenyves V., Dajnoki K., Szabados Gy. (2018): Sportszolgáltatások kínálatának elemzése szervezeti szempontok alapján. International Journal of Engineering and Management Sciences, 3 (4): 465-474.

Bácsné Bába É. (2014a): Festival in Tune with Students. In: Magdolna Láczay, Dariusz Fatula (szerk.): Social Aspects of Management: Personal Development, cultural changes, economic progress. Kraków: Krakow Society for Education; AFM Publishing House. 75-88. 
Bácsné Bába É. (2014b): Hallgatók, buli, Campus - Felsőoktatási hallgatók fesztivállátogatási szokásainak változása a Campus Fesztivál vizsgálata alapján. Turizmus Bulletin 14 (2): 34-41.

Boda E., Bácsné Bába É., Müller A. (2018): Motiváció vizsgálata a kalandpark-látogatók körében. International Journal of Engineering and Management Sciences, 3 (3): 106-126.

Chikán A., Demeter K. (1999): Az értékteremtő folyamatok menedzsmentje - termelés, szolgáltatás, logisztika. Aula Kiadó, Budapest.

Dumond, E. J. (2000): Value management: an underlying framework. International Journal of Operation \& Production Management, 20 (9): 1062-1077.

Halassy E. (1999): Beszámoló a WTO 1998. évi krakkói konferenciájáról. <http://old.Hungary tourism.hu/bulletin/regi/99_03/forum_1.html> (2018.09.10.)

Jónás-Berki M. (2010): Tematikus parkok a turizmus rendszerében. Kalandparkok modellje induktív szemleletben. 2010. Pécs, PhD tézisek. <http://old.foldrajz.ttk.pte.hu/phd/phdkoord/nv/tezis/ tezis_berki_nv.pdf> (2018.03.10)

Jones, T. O., Sasser, W. E. Jr. (1995): Why Satisfied Customers Defect. Harvard Business Review, 73 (6): 88-99.

Könyves E., Müller A. (2007): A minőségi díj megítélése az egészségturisztikai szolgáltatók marketingkommunikációs eszközrendszerében. In: Acta Academiae Pedagogicae Agriensis, Úk sorozat 34: 57-69.

Könyves E., Müller A., Lázárné Fodor I. (2006a): Quality aspects of Rural Tourism. V. alföldi Tudományos Tájgazdálkodási Napok. Szolnoki Főiskola Műszaki és Mezőgazdasági FakultásRural- and Region Development, Rural Turism szekció. 2006. okt.26-27. In: V. Alföldi Tudományos Tájgazdálkodási Napok konferencia cd kiadványában.

Könyves E., Müller A., Szalay F., Szabó R. (2005): Cserkeszőlő és Karcag egészség-turizmusának összehasonlító elemzése. In: Szolnoki Tudományos Közlemények IX. (cd).

Könyves E., Müller A. (2001): Szabadidős programok a falusi turizmusban. Könyv. Szaktudás Kiadó Ház, Budapest.

Müller A., Kórik V. (2009): Az Észak-alföldi fürdők szerepe a turizmusban és a rekreációban. In: Economica, 2 (2): 58-72.

Müller A., Boda E. J., Ráthonyi G., Ráthonyi-Ódor K., Barcsák B., Könyves Erika, Bíró M., Dobay B., Bendíkova E. (2016): Analysis of the cavebath of Miskolctapolca's brand elements and guests satisfaction. In: Apstract - Applied Studies In Agribusiness And Commerce, 10 (4-5): $155-160$.

Müller A., Könyves E., Honfi L., Szabó R. (2009): A hazai barlangok ismertsége és szerepe a turizmusban. In: Acta Academiae Pedagogicae Agriensis, 35: 37-50.

Müller A., Könyves E., Lázárné Fodor I. (2006b): Minőségi turizmus avagy minőség a turizmusban. Tudomány Napi Konferencia Szolnok. Nov.8. In: Szolnoki Tudományos Közlemények X.

Oxygen Adrenalin Park honlapja. <https://adrenalin-park.hu/> (2018. 09. 24.)

Papp I. (szerk.) (2003): Szolgáltatások a 3. évezredben. Aula Kiadó, Budapest.

Papp K., Rózsa A. (2003): Szolgáltatásminőség elméletben és gyakorlatban. Marketing \& Menedzsment, 37 (5): 4-13.

Parasuraman, A., Zeithaml, V. A., Berry, L. L. (1985): A conceptual model of service quality and Its Implications for Future Research. In: Journal of Marketing, 49 (4): 41-50.

Ryan, C., Shih, Shuo Y., Huan, T. C. (2010): Theme parks and a structural equation model of determinants of visitor satisfaction: Janfusan Fancyworld, Taiwan. Journal of Vacation Marketing, 16 (3): 185-199.

Zemplén Kalandpark honlapja. <http://www.zemplenkalandpark.hu/> (2019.09.24) 